\title{
Alpha fucosidase and beta galactosidase in serum of a Lyme disease patients as a possible marker of accelerated senescence - a preliminary study
}

\author{
Anna Wasiluk ${ }^{1}$, Napoleon Waszkiewicz ${ }^{2}$, Sławomir Dariusz Szajda ${ }^{1}$, \\ Marzena Wojewódzka-Żelezniakowicz ${ }^{1}$, Alina Kępka ${ }^{3}$, Alina Minarowska ${ }^{4}$, \\ Zbigniew Wojciech Zwierz ${ }^{5}$, Sławomir Pancewicz ${ }^{6}$, Beata Zalewska-Szajda ${ }^{7}$, \\ Jerzy Robert Ładny', Krzysztof Zwierz ${ }^{5}$
}

${ }^{1}$ Department of Emergency Medicine and Disasters, Medical University of Bialystok, Poland

${ }^{2}$ Department of Psychiatry, Medical University of Bialystok, Poland

${ }^{3}$ Department of Biochemistry and Experimental Medicine, the Children's Memorial

Health Institute of Warsaw, Poland

${ }^{4}$ Department of Anatomy, Medical University of Bialystok, Poland

${ }^{5}$ Medical College the Universal Education Society, Lomza, Poland

${ }^{6}$ Department of Infectious Diseases and Neuroinfections, Medical University of Bialystok, Poland

${ }^{7}$ Department of Imaging Diagnostic, Medical University of Bialystok, Poland

\begin{abstract}
Lyme disease (LD) is the most prevalent tick-borne disease in Europe. LD is caused by the spirochete Borrelia burgdorferi. LD is a chronic disease which can attack a number of organs: skin, heart, brain, joints. Chronic, low-grade inflammation involves general production of pro-inflammatory cytokines and inflammatory markers and is a typical feature of aging. So far, the best method of diagnosing LD is a time-consuming and expensive two-stage serological method. The aim of our study was to evaluate the activity of two lysosomal exoglycosidases: $\alpha$-fucosidase (FUC) and $\beta$-galactosidase (GAL) in the serum of patients with Lyme disease, as potential markers of LD. Due to the increasing number of patients with Lyme disease and a number of false results, new ways to diagnose this disease are still being sought. As elevated level of $\beta$-galactosidase is a manifestation of residual lysosomal activity in senescent cells, the increase in its activity in serum during chronic Lyme disease might be a marker of a potentially accelerated senescence process. The study was performed on serum taken from cubital veins of 15 patients with Lyme disease and eight healthy subjects (control group). FUC and GAL activity was measured by the method of Chatterjee et al. as modified by Zwierz et al. In the serum of patients with Lyme disease, GAL activity significantly increased $(p=0.029)$, and the activity of FUC had a tendency to increase $(p=0.153)$, compared to the control group. A significant increase in GAL activity in the serum of patients with Lyme disease indicates an increased catabolism of glycoconjugates (glycoproteins, glycolipids, proteoglycans) and could be helpful in the diagnosis of Lyme disease, although this requires confirmation in a larger group of patients. As GAL is the most widely used assay for detection of senescent cells, an elevated level of $\beta$-galactosidase might be a manifestation of accelerated senescence process in the course of Lyme disease. (Folia Histochemica et Cytobiologica 2012, Vol. 50, No. 2, 270-274)
\end{abstract}

Key words: Lyme disease, alpha-fucosidase, beta-galactosidase, Borrelia burgdorferi, senescence

Correspondence address: S.D. Szajda,

Department of Emergency Medicine and Disasters,

Medical University of Bialystok,

Waszyngtona Str. 15a, 15-274 Bialystok, Poland;

tel.: + 488574508 05, tel./fax: + 488574508 04;

e-mail: sbszajda@gmail.com 


\section{Introduction}

Lyme disease (LD) is a bacterial disease caused by the spirochete Borrelia burgdorferi, transferred to humans by infected Ixodes ricinus ticks [1-3]. After the bite of a Borrelia burgdorferi infected tick, spirochetes penetrate human skin within 48 hours, and after 72 hours the risk of infection is $100 \%$ [4]. Lyme disease is endemic in Europe, America and northern regions of Asia [5]. In Europe, LD is most common in the forested areas of Scandinavia, and Central Europe, especially Germany, Austria, and Slovenia [6]. In Poland, LD is the commonest tick-borne disease and is becoming a serious epidemiological problem [7]. Australia, Africa, South America and southern parts of the United States are considered free of the disease [5]. In Poland, the biggest threat of Lyme disease occurs in forested areas: Podlasie, Maritime Province, West Polish Lake District, Carpathian Mountains, and Karkonosze [6]. Exposure to Lyme disease involves those in endemic areas, mostly forestry workers, collectors of wild products in the forests, as well as tourists visiting forest areas [5, 7]. The disease occurs with similar frequency in men and women and can develop at any age [5]. Lyme disease is characterized by a broad spectrum of symptoms in many organs involved: skin, heart, brain and joints [1]. So far, the best method of diagnosing LD is a time-consuming and expensive two-stage serological method. Due to an increasing number of patients with Lyme disease and a number of false results, new ways to diagnose LD are still being sought. Our research is based on the fact that Borrelia burgdorferi associates with epithelial glycosaminoglycans (components of proteoglycans) and glycosphingolipids located on the surface of neuronal cells [8]. It is known that Borrelia burgdorferi infection causes an immunological response. Immunological response provokes increase in metabolism of the glycoconjugates (glycoproteins, glycolipids and proteoglycans) $[9,10]$, which constitute cell membranes and extracellular matrix [11]. Beta-GAL expression has been shown to be a reliable indicator of the switch mechanism used by cells to enter senescence [12]. The senescent phenotype displays distinct morphological characteristics where cells become enlarged and flattened with increased granularity and a vacuole-rich cytoplasm [13].

Catabolism of glycoconjugates occurs in lysosomes. In lysosomes the protein parts of glycoconjugates are degraded by proteases and sugar chains by glycosidases, which include $\alpha$-fucosidase (FUC), and $\beta$-galactosidase (GAL) [14].

FUC is a lysosomal exoglycosidase [15], which cleaves $\alpha$-fucose from oligosaccharides [14, 16]. Par- ticipation of lysosomal FUC is essential in the catabolism of glycoproteins and complex fucoglycolipids e.g. blood group substances [17]. It has been shown that the presence of FUC correlates with the expression of Lewis $x\left(\operatorname{Lex}^{x}\right)$ antigen [16]. Approximately $10-15 \%$ of the total FUC activity is located on the surface of human cells (mesenchymal and liver cells) [18]. FUC is characterized by considerable tissue heterogeneity. In the body, FUC is present in specific tissues, but some tissues do not contain the alleles of the gene for FUC [18].

GAL (commonly known as lactase) participates in catabolism of glycoconjugates possessing D-galactose connected by $\beta$-glycosidic bounds to other sugars of the oligosaccharide chains [19]. GAL releases D-galactose from nonreducing ends of oligosaccharide chains of glycoproteins, glycolipids and glycosaminoglycans $[19,20]$. GAL with equal intensity hydrolyzes lactose and O-nitrophenol-B-D-galactopyranoside [21].

The aim of this study was to evaluate the activity of the lysosomal exoglycosidases FUC and GAL in the serum of patients with Lyme disease.

\section{Material and methods}

Material for the study was serum obtained from venous blood of patients with Lyme disease, before treatment. The study included 15 patients (six women and nine men aged 41-63 years, mean age $56 \pm 10.43$ years) hospitalized in the Department of Infectious Diseases and Neuroinfections at the Medical University of Bialystok. Lyme disease was diagnosed clinically according to the European Center for Disease Control and Prevention, based on tick biting, and erythema in place of biting in anamnesis, as well as two-step serological investigation (positive ELISA and Western blot tests in direction to Borrelia burgdorferi). Control serum was obtained from blood collected from eight healthy adults (four women and four men). Age range of the control group was 31-71 years (mean age $50 \pm$ \pm 13.42 years). The study was approved by the local Committee for Human Reserch (RI-002/202/2011), and was performed according to guidelines for good clinical practice. Venous blood was taken from the cubital veins (without anticoagulant) into sterile tubes, and left for $30 \mathrm{~min}-$ utes at $4^{\circ} \mathrm{C}$ for clotting and clot retraction. After this time, the serum was centrifuged at $3,500 \times \mathrm{g}$ for 10 minutes at $4^{\circ} \mathrm{C}$. The serum was stored at $80^{\circ} \mathrm{C}$ before use. $\alpha$-fucosidase (FUC), and $\beta$-galactosidase (GAL) activity (pKat/ $/ \mathrm{ml}$ of blood serum) was determined spectrophotometrically using 4-nitrophenyl- $\alpha$-L-fucopyranoside and p-nitrophenyl $\beta$-D-galactopyranoside (Sigma-Aldrich) as substrates, following the method of Chatterjee et al. [22] as modified by Zwierz et al. [23]. 


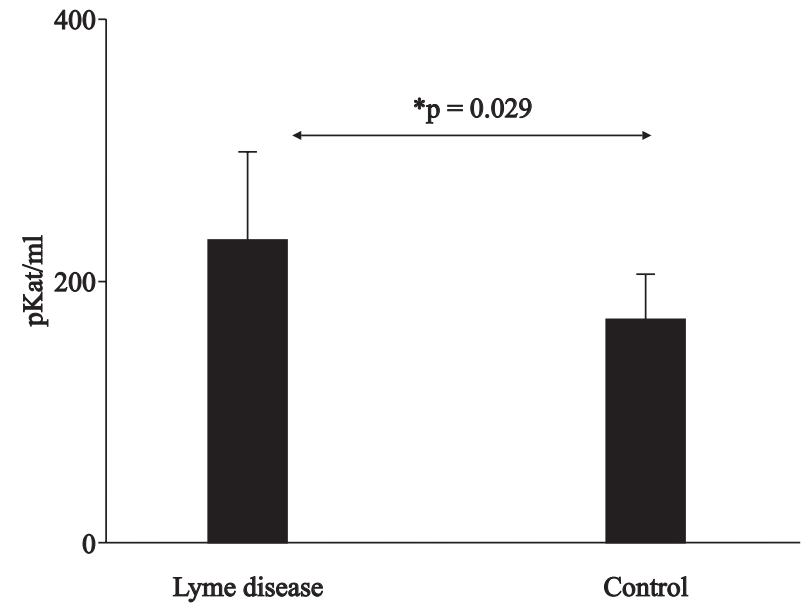

Figure 1. Activity of $\beta$-galactosidase in serum of patients with Lyme disease

The results were analyzed by statistical package SPSS ${ }^{\circledR}$ for Windows PL (SPSS, Chicago, IL, USA) according to the Mann-Whitney test. The statistical significance of differences was regarded to be $\mathrm{p}<0.05$.

\section{Results}

The concentration of GAL and FUC activity in the serum of patients with Lyme disease was $286.62 \pm$ $\pm 64.01 \mathrm{pKat} / \mathrm{ml}$ for GAL, and $234.59 \pm 66.33 \mathrm{pKat} /$ $/ \mathrm{ml}$ for FUC, and was $234.95 \pm 69.96 \mathrm{pKat} / \mathrm{ml}$ for GAL, and $176.61 \pm 30.71 \mathrm{pKat} / \mathrm{ml}$ for FUC in the serum of healthy persons (Figures 1,2). The concentration of GAL activity in the serum of patients with Lyme disease was significantly higher $(p=0.029)$ compared to the activity in the blood serum of healthy individuals (Figure 1). There was a trend to increase the concentration of FUC activity in the serum of patients with Lyme disease in comparison with the FUC concentration in the serum of healthy individuals (Figure 2).

\section{Discussion}

Lyme disease is the commonest tick-borne disease in Europe [24, 25]. The disease is characterized by a chronic phase and varied course of the clinical picture [26]. Lyme disease affects in particular the skin, central and peripheral nervous system, heart, musculoskeletal system, and joints [2, 25-28]. Iżycka et al. [29], in examining the expression of CD43 and PSGL particles-1 on the neutrophils of patients with Lyme disease, found an increase in the concentration of the soluble form of PSGL-1 (sPSGL-1). PSGL is a ligand for P- and E-selectins involved in the first stage of

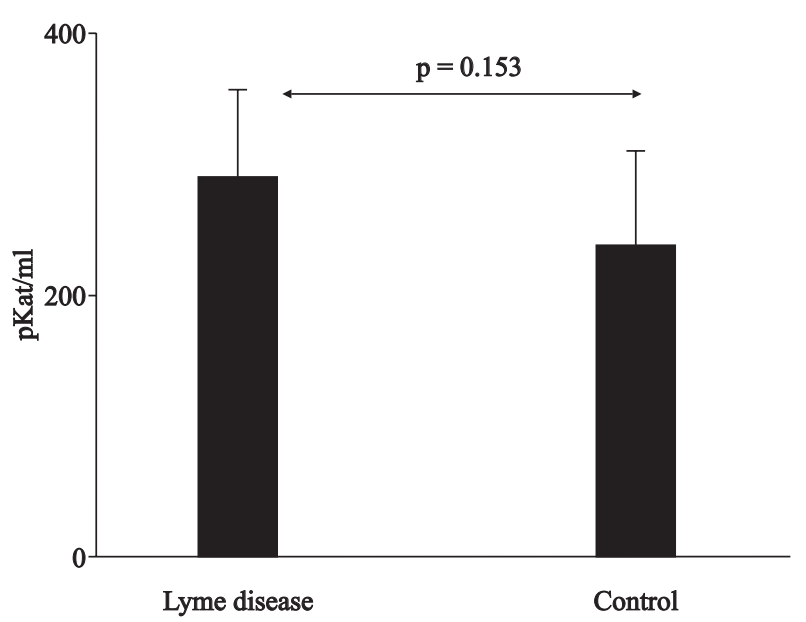

Figure 2. Activity of $\alpha$-fucosidase in serum of patients with Lyme disease

adhesion, which occurs during margination and rolling neutrophils. Increasing concentration of sPSGL-1, by blocking specific membrane ligands on neutrophils, leads to inhibition of neutrophils adhesion and promotes long-term persistence of the inflammatory process [29].

Lyme disease is difficult to diagnose and eradicate [30], because of the unique features of the spirochete Borrelia burgdorferi and high affinity of the spirochete for connective tissue, muscle and nervous tissue [27]. Lyme disease has uncharacteristic symptoms and can mimic many diseases, which in turn contributes to errors in diagnosis. Often, the patient is treated by different specialists, and the late diagnosis reduces the chances of spirochete elimination [27, 31]. Lyme disease is diagnosed by serological detection of the $\mathrm{IgG}$ and $\mathrm{IgM}$ antibodies directed against Borrelia burgdorferi antigens. A two-step method is recommended, in which the screening test is an ELISA, while the confirming test is a Western blot. The test is performed both in serum and CSF (in the case of neuroboreliosis) [32-34]. However, even the introduction of routine testing for Lyme disease and Western blot confirmatory test does not solve completely the problems of laboratory diagnosis of Lyme disease. This is because the test is designed to detect specific antibodies which may cover antigens derived from species of Borrelia burgdorferi which do not occur in diagnosed patients [35].

For routine diagnosis of Lyme disease, we do not recommend the use of $\mathrm{PCR}$, microscopic examination or culture. PCR is not sufficiently standardized and uses a variety of primers and different genes as starting materials; therefore the results obtained in different centers are not comparable. Microscopic 
studies show a high percentage of false results due to the small number of spirochetes in biological material $[27,34]$.

As more and more people suffer from Lyme disease, alternative methods of diagnosing the disease are being proposed. Our research is based on the reported changes of the serum [28, 36-38] and urine $[39,40]$ exoglycosidases activity in Lyme disease. Pancewicz et al. [28], in studying the activity of lysosomal exoglycosidases in serum and synovial fluid of patients with Lyme arthritis, noticed a significant increase in the activity of these enzymes in the blood serum of Lyme disease patients, compared to controls. They observed the largest increase in HEX activity. Pancewicz et al. [28] suggested that the activity of HEX can be used to monitor Lyme disease and assess the effectiveness of treatment of patients with Lyme arthritis [28]. Knaś et al. [39] found only a tendency to increase in the activity of the urinary exoglycosidases in Lyme disease patients compared to exoglycosidases activity in urine collected from healthy individuals. Similar results were obtained by Choromanska et al. [40], where the only enzyme showing increased activity in the urine of Lyme disease patients was HEX. We decided to check the serum activity of $\alpha$-fucosidase and $\beta$-galactosidase the lysosomal exoglycosidases involved in hydrolysis of the oligosaccharide chains of glycolipids, glycoproteins and proteoglycans [19]. As preliminary studies on the activity of GAL and FUC in the serum of patients with Lyme disease showed a tendency for the activity of both enzymes in the serum of patients to increase compared to the sera of healthy individuals [37], we decided to conduct further studies on a larger group of patients with Lyme disease to determine whether the upward trend is not caused only by a small quantity of patients in the tested group. In our present study, we found that only the activity of $\beta$-galactosidase was significantly higher in the serum of patients with Lyme disease, compared to its activity in healthy subjects $(p=0.029)$ (Figure 1$)$, whereas the activity of $\alpha$-fucosidase in the serum of patients with Lyme disease had only a tendency to increase, compared to the activity of FUC, in the blood serum of healthy individuals $(\mathrm{p}=0.153)$ (Figure 2).

As mentioned before, Lyme disease promotes long-term persistence of the inflammatory process. A typical feature of aging is a chronic low-grade inflammatory process, characterized by a general increase in the production of pro-inflammatory cytokines and inflammatory markers [41]. This immunosenescence process is explained by an imbalance between inflammatory and anti-inflammatory networks. It results in low grade chronic pro-inflammatory sta- tus and it has been suggested it be called 'inflammaging' [42]. An elevated level of (beta)-galactosidase is a manifestation of increased residual lysosomal activity, which becomes detectable due to the increased lysosomal content in senescent cells [43]. In our study, elevated activity of only GAL might be the result of an accelerated senescence process due to the 'inflammaging'. Earlier studies have noted elevated serum levels of all exoglycosidases including GAL and FUC in LD [28]. However, this might be due to the very active synovial inflammation following exoglycosidases release.

\section{Conclusions}

1. A significant increase in GAL, but not FUC, activity in the serum of patients with Lyme disease indicates on participation of GAL in increased remodeling of tissues glycoconjugates connected with inflammation caused by Borrelia burgdorferi infection.

2. Increase in serum GAL activity might be helpful in the diagnosis of Lyme disease, although this conclusion should be confirmed by a study in a larger group of patients.

3. An elevated level of $\beta$-galactosidase might be a manifestation of accelerated senescence process in the course of Lyme disease.

\section{Acknowledgments}

We are grateful to Dr Tony Merry from Manchester University for critical reading of the manuscript. The paper was supported by the Medical University of Białystok to the Department of Pharmaceutical Biochemistry.

\section{References}

1. Maroszyńska-Dmoch E, Wożakowska-Kapłon B. Borelioza z Lyme - niedoceniany problem w praktyce kardiologa. Folia Cardiol Exc. 2008;3:375-382.

2. Kajfasz P. Borelioza. Pol Prz Med Lot. 2006;12:379-384 .

3. Niu Q, Guan G, Yang J et al. Detection and differentiation of Borrelia burgdorferi sensu lato in ticks collected from sheep and cattle in China. BMC Vet Res. 2011;7:17.

4. Wagner T, Legatowicz-Koprowska M, Prochorec-Sobieszek M. Clinico-pathological collations in borreliosis. Pol Merkur Lek. 2006;20:731-734.

5. Owecki MK, Kozubski W. Clinical spectrum of neuroborreliosis. Wiad Lek. 2007;60:167-170.

6. Rydz-Stryszowska I, Batko B, Krawiec P, Krzanowski M, Jurek-Krawiec M, Skura A. Lyme arthritis. Przegl Lek. 2007; 64:111-114.

7. Dobracki W, Dobracka B, Paczosa W, Zięba J, Bereś P. Epidemiology of borreliosis in workers of the district forestry offices in Lower Silesia. Przegl Epidemiol. 2007;61:385-391. 
8. Zajkowska JM, Hermanowska-Szpakowicz T, Pancewicz SA, Kondrusik M. Selected aspects of immunopathogenesis in Lyme disease. Pol Merkur Lek. 2000;9:579-583.

9. Knaś M, Stypułkowska A, Lukivskaja O, Borzym-Kluczyk M, Buko V, Zwierz K. Effects of statins on liver fibrosis reversibility and activities of lysosomal exoglycosidases: Part II. Exp Clin Hepatology. 2009;5:32-34.

10. Murray RK. Glycoproteins: Crucial Molecules for Health. GlycScience \& Nutrition. 2003;4:1-10.

11. Nau R, Christen HJ, Eiffert H. Lyme disease current state of knowledge. Dtsch Arztebl Int. 2009;106:72-81.

12. Struewing IT, Durham SN, Barnett CD, Mao CD. Enhanced endothelial cell senescence by lithium-induced matrix metalloproteinase-1 expression. J Biol Chem. 2009;284:17595$-17606$.

13. Schmitt CA. Cellular senescence and cancer treatment. Biochim Biophys Acta. 2007;1775:5-20.

14. Zwierz K, Midro AT. Metabolic disorders in patients with primary carbohydrate deficient glycoprotein syndrome. Postępy Hig Med Dosw. 1997;51:205-226.

15. Waszkiewicz N, Szajda SD, Jankowska A et al. Catabolism of alivary glycoconjugates in acute ethanol intoxication. $\mathrm{Med} \mathrm{Sci}$ Monit. 2009;15:CR413-417.

16. Ashida H, Miyake A, Kiyohara $M$ et al. Two distinct $\alpha$-L-fucosidases from Bifidobacterium bifidum are essential for the utilization of fucosylated milk oligosaccharides and glycoconjugates. Glycobiology. 2009;19:1010-1017.

17. Ostrowska L, Zwierz K, Koniusz Z, Gindzieński A. Function, properties and clinical significance of N-acetyl-beta-D-hexosaminidase. Postepy Hig Med Dosw. 1993;47:67-79.

18. Ali S, Jenkins Y, Kirkley M, Dagkalis A, Manivannan A, Crane IJ, Kirby JA. Leukocyte extravasation: an immunoregulatory role for $\alpha$-L-Fucosidase? J Immunol. 2008;181: 2407-2413.

19. Szajda SD, Snarska J, Borzym-Kluczyk M et al. Aktywność $\beta$-galaktozydazy i $\alpha$-mannozydazy w surowicy krwi chorych z rakiem jelita grubego. Wspótcz Onkol. 2007;11:64-66.

20. Wanarska M, Kur J. $\beta$-D-galactosidases sources, properties and applications. Biotechnologia. 2005;4:46-62.

21. Poznański S, Kowalewska J, Bednarski W, Reps A. Obtaining, properties and application of beta-galactosidase in food technology. Postępy Biochem. 1975;21:437-443.

22. Chatterjee S, Velicer LF, Sweeley CC. Glycosphingolipid glycosyl hydrolases and glycosidases of synchronized human $\mathrm{KB}$ cells. J Biol Chem. 1975;250:4972-4979.

23. Zwierz K, Gindzieński A, Głowacka D, Porowski T. The degradation of glycoconjugates in the human gastric mucous membrane. Acta Med Acad Sci Hung. 1981;38:145-152.

24. Kjelland V, Stuen S, Skarpaas T, Slettan A. Borrelia burgdorferi sensu lato in Ixodes ricinus ticks collected from migratory birds in Southern Norway. Acta Vet Scand. 2010;6:59.

25. www.pteilchz.org.pl/standardy.htm „Diagnostyka i Leczenie Boreliozy z Lyme zalecenia Polskiego Towarzystwa Epidemiologów i Lekarzy Chorób Zakaźnych" (24.11.2010).

26. Rolla-Szczepańska R. Borelioza choroba z Lyme. Med Og. 2007;13:8593.

27. Pawińska A. Borelioza z Lyme diagnostyka mikrobiologiczna i leczenie. Stand Med. 2009;6:757-766.
28. Pancewicz S, Popko J, Rutkowski R et al. Activity of lysosomal exoglycosidases in serum and synovial fluid in patients with chronic Lyme and rheumatoid arthritis. Scand J Infect Dis. 2009;41:584-589.

29. Iżycka A, Jabłońska E, Ziarko S, Radziwon P, Zajkowska J, Pancewicz S. Ekspresja cząsteczek CD 43 i PSGL-1 na neutrofilach chorych na boreliozę z Lyme. Przegl Med Uniw Rzesz. 2010;8:14-20.

30. Zajkowska J. Borelioza z Lyme standardy leczenia a oczekiwania chorych. Przegl Epidemiol. 2008;62(Suppl.1):142$-151$.

31. Cameron D, Gaito A, Harris N et al. Evidence-based guidelines for the management of Lyme disease. Expert Rev Anti Infect Ther. 2004;2:S1-13.

32. Stanisławska-Biernat E. Współczesne podejście do diagnostyki i leczenia boreliozy. Terapia. 2006;14:57-60.

33. Tylewska-Wierzbanowska S, Chmielewski T. Borelioza z Lyme rozpoznanie kliniczne i laboratoryjne. Nowa Klin. 2008;15: $565-570$.

34. Flisak R, Pancewicz S, Grygorczuk S et al. Diagnostyka i leczenie boreliozy z Lyme zalecenia Polskiego Towarzystwa Epidemiologów i Lekarzy Chorób Zakaźnych. Świat Med Farm. 2009;7:22-25.

35. Cisak E, Chmielewska-Badora J, Zwoliński J et al. Charakterystyka testów Western blot stosowanych w diagnostyce boreliozy u ludzi. Med Og. 2009;15:514-525.

36. Wielgat P, Pancewicz S, Hermanowska-Szpakowicz T et al. Activity of lysosomal exoglycosidases in serum of patients with chronic borrelia arthritis. Przegl Epidemiol. 2004;58: 451-458.

37. Wasiluk A. Activity of $\alpha$-fucosidase and $\alpha$-galactosidase in blood serum of patients with Lyme boreliosis. $6^{\text {th }}$ Bialystok International Medical Congress for Young Scientists. 2011:196.

38. Szajda SD, Knaś M, Luto M et al. Influence of Lyme borreliosis on the activity of lysosomal hydrolases in serum. Acta Biochim Pol. 2009;56(Suppl. 3):196.

39. Knaś M, Szajda SD, Choromańska B et al. Influence of Lyme borreliosis on the activity of lysosomal hydrolases in urine. Acta Biochim Pol. 2009;56:197.

40. Choromańska B, Luto M, Abramowicz W, Chwiła A, Wasiluk A. Ocena aktywności N-acetylo-beta-heksozoaminizady, jej izoenzymu B oraz beta-glukuronidazy w moczu chorych na boreliozę. Książka abstraktów: 5 Międzynarodowej Konferencji Naukowej Studentów Medycyny i Młodych Lekarzy, 2010:171.

41. Cevenini E, Caruso C, Candore G et al. Age-related inflammation: the contribution of different organs, tissues and systems. How to face it for therapeutic approaches. Curr Pharm Des. 2010;16:609-618.

42. Franceschi C, Capri M, Monti D et al. Inflammaging and anti-inflammaging: a systemic perspective on aging and longevity emerged from studies in humans. Mech Ageing Dev. 2007;128:92-105.

43. Kurz DJ, Decary S, Hong Y, Erusalimsky JD. Senescence-associated beta-galactosidase reflects an increase in lysosomal mass during replicative ageing of human endothelial cells. J Cell Sci. 2000;113:3613-3622.

Submitted: 22 September, 2011

Accepted after reviews: 10 January, 201 